\title{
Systematic review on human resources for health interventions to improve maternal health outcomes: evidence from low- and middle-income countries
}

Zohra S. Lassi ${ }^{1}, 2$, Nabiha B. Musavi ${ }^{1}$, Blerta Maliqi ${ }^{3}$, Nadia Mansoor ${ }^{1}$, Andres de Francisco ${ }^{4}$, Kadidiatou Toure ${ }^{4}$ and Zulfiqar A. Bhutta ${ }^{5,6^{*}}$

\begin{abstract}
There is a broad consensus and evidence that shows qualified, accessible, and responsive human resources for health $(\mathrm{HRH})$ can make a major impact on the health of the populations. At the same time, there is widespread recognition that $\mathrm{HRH}$ crises particularly in low- and middle-income countries (LMICs) impede the achievement of better health outcomes/targets. In order to achieve the Sustainable Development Goals (SDGs), equitable access to a skilled and motivated health worker within a performing health system is need to be ensured. This review contributes to the vast pool of literature towards the assessment of $\mathrm{HRH}$ for maternal health and is focused on interventions delivered by skilled birth attendants (SBAs). Studies were included if (a) any HRH interventions in management system, policy, finance, education, partnership, and leadership were implemented; (b) these were related to SBA; (c) reported outcomes related to maternal health; (d) the studies were conducted in LMICs; and (e) studies were in English. Studies were excluded if traditional birth attendants and/or community health workers were trained. The review identified 25 studies which revealed reasons for poor maternal health outcomes in LMICs despite the efforts and policies implemented throughout these years. This review suggested an urgent and immediate need for formative evidence-based research on effective HRH interventions for improved maternal health outcomes. Other initiatives such as education and empowerment of women, alleviating poverty, establishing gender equality, and provision of infrastructure, equipment, drugs, and supplies are all integral components that are required to achieve SDGs by reducing maternal mortality and improving maternal health.
\end{abstract}

Keywords: Human resources for health, Maternal mortality, Skilled birth attendant, Low- and middle-income countries

\section{Background}

Maternal health is one of the main global health challenges in which least progress was witnessed in the year 2015 [1]. Hence, greater progress is required to meet the newly developed Sustainable Development Goals (SDGs) by ensuring equitable access to a skilled and motivated health worker within a performing health system. Less than $1 \%$ of the annual maternal deaths occur in the

\footnotetext{
* Correspondence: zulfiqar.bhutta@sickkids.ca

${ }^{5}$ Center of Excellence in Women and Child Health, Aga Khan University, Karachi, Pakistan

${ }^{6}$ Centre for Global Child Health, The Hospital for Sick children, Toronto, Canada

Full list of author information is available at the end of the article
}

developed world, while a large proportion of these occur in low- and middle-income countries (LMICs). Further, for every woman dying, at least 30 others suffer complications which often end up being long-term and devastating which includes infertility and damage to the reproductive organs. It is widely agreed that there is not a single straightforward intervention, which can bring significant decrease in maternal mortality, but it can only be addressed by strengthening and providing an efficient health system with the provision of trained health workers being its key component [2-4]. The shortage of health workers was the most significant constraint noticed for not attaining the three health-related 
Millennium Development Goal (MDG) targets by many countries [3, 5-8].

Unfortunately, the workforce is distributed unevenly $[9,10]$. Asia, a continent with half of the world's population, has access to only $30 \%$ of the world's health professionals [11]. Africa, with the highest burden of disease, has access to only $1 \%$ of the world's health professionals [11]. Whereas America which has $10 \%$ of the global burden of disease has approximately $40 \%$ of the world's health professionals [11]. The scenario within each country also shows asymmetry in the distribution of health professionals with low number of professionals in the rural compared to urban areas [12, 13]. Apart from mal-distribution, many countries face difficulties in recruiting and retaining health professionals. Insufficient number of medical schools, low salaries of the existing health workforce, poor working conditions, lack of supervision, low morale and motivation, and lack of infrastructure are few prominent causes for the loss of health professionals, where they immigrate to wealthier countries [14-18].

The shortage of emergency obstetric care (EmOC) and surgical services in LMICs over the last decade has attracted substantial attention [19-22]. In response, governments, health organizations, and communities have taken actions to address human resources for health $(\mathrm{HRH})$ needs. There is a substantial evidence that highlights initiatives and innovative actions which have increased efficiency in utilizing existing human resources, including team approaches for delivery of intervention, multi-tasking, task shifting and sharing, and increased involvement by the communities [23]. However, most of them are implemented on a small scale or at limited capacity. In this context, it is important to realize that there is immense need for better planning, distribution, and management of limited human resources to address SDGs and strong need for formative evidence learned through lessons towards achieving this goal. This review has focused on the impact of HRH interventions for maternal health delivered by skilled birth attendants (SBAs) $[24,25]$ (Table 1). We have also derived lessons, identified research gaps, and formulated recommendations based on the studies from LMICs.

\section{Methods}

The review derived evidence from randomized controlled trials (RCTs), quasi-RCTs, and prospective before/after and cohort studies on SBAs working at the national, provincial, district, and community levels (home, community or referral facility interventions). Studies were included if (a) they implemented any HRH interventions in management system, policy, finance, education, partnership, and leadership; (b) those were related to SBAs; (c) have reported outcomes related to maternal health such as changes in morbidity, mortality, coverage, or other interrelated outcomes; (d) were conducted in LMICs [26]; and (e) were written in English. Studies in which traditional birth attendants and/or community health workers were trained were excluded.

The search strategy included PubMed articles published from January 2000 to December 2015. The reason to select this time period was to evaluate what progress has been made since the 2000 deadline of the Alma Ata health for all and what improvements followed on the agreement on MDGs. The HRH Global Resource Centre was also searched to access the available studies. Detailed examination of cross-references and bibliographies of identified studies was also performed to identify additional sources of information. The following search strategy was primarily used. [("health worker" OR "health care worker" OR "health professional" OR "health personnel" OR doctor* OR nurse* OR physician* OR midwi* OR "nurse midwi" ${ }^{*}$ " OR "skilled birth attendant"*) AND (training OR education OR curriculum OR teaching OR learning OR "patient centered care" OR "patient focused care" OR "staff development" OR medicine OR "postgraduate training" OR "diploma training" OR recruitment OR attraction OR deployment OR employment OR personnel selection OR incentive OR reward OR "cash award")]. The quality of RCTs and quasiRCTs was assessed using the Cochrane methods [27]; however, the quality of prospective studies/pre-post trials was assessed using the criteria adopted from Loevinsohn (Table 2) [28]. To assess the different dimensions of the HR planning and management spectrum, this review used the HRH action framework (Fig. 1) as defined by WHO [29]. The framework has six action fields, each

Table 1 Definition of skilled birth attendant and skilled birth attendance

\begin{tabular}{l} 
Skilled birth attendant \\
\hline A joint WHO/ICM/FIGO statement, endorsed by UNFPA and the World \\
Bank defines a skilled attendant as "an accredited health professional, \\
such as a midwife, doctor or nurse, who has been educated and trained \\
to proficiency in the skills needed to manage normal (uncomplicated) \\
pregnancies, childbirth and the immediate postnatal period, and in the \\
identification, management and referral of complications in women and \\
newborns" [79].
\end{tabular}

Source: DFID 2005 [82]
Skilled birth attendance

Skilled attendance is the process by which a pregnant woman and her infant are provided with adequate care during pregnancy, labor, birth, and the postpartum and immediate newborn periods, whether the place of delivery is the home, health center, or hospital. In order for this process to take place, the attendant must have the necessary skills and must be supported by an enabling environment at various levels of the health system, including a supportive policy and regulatory framework; adequate supplies, equipment, and infrastructure; and an efficient and effective system of communication and referral/transport $[80,81]$. 
Table 2 Quality assessment criteria for pre-post studies without control arm

\begin{tabular}{ll}
\hline Study features $^{\text {a }}$ & Assessment \\
\hline 1. Study based on explicit theory & Yes/no/unclear \\
2. Adequate description of how intervention & Yes/no/unclear \\
strategy adapted to local conditions & \\
3. Example given of materials or process & Yes/no/unclear \\
4. Adequate description of resources required & Yes/no/unclear \\
to carry out interventions & \\
5. Measure outcome before and after intervention & Yes/no/unclear \\
6. Measurement method same before and after & Yes/no/unclear \\
7. Period between education and outcome more & Yes/no/unclear \\
than 1 year & \\
8. Author claimed positive results for interventions & Yes/no/unclear \\
9. Paper included discussion of possible biases and & Yes/no/unclear \\
caveats (or limitations) & \\
10. Paper included $P$ values or confidence interval & Yes/no/unclear \\
11. Analysis employed some form of modeling & Yes/no/unclear \\
such as regression & \\
12. Exposure to intervention monitored & Yes/no/unclear \\
aAdopted from Loevinsohn [28]
\end{tabular}

of which has several areas of intervention. For a better response to $\mathrm{HRH}$ crises, each of the six action fields needs to be addressed. These are described in Table 3.

\section{Results}

The defined search strategy identified 4565 studies. Of these, 217 were retrieved for full-text review; however, only 25 papers passed the eligibility criteria for inclusion (Fig. 2). Studies were grouped and analyzed according to different dimensions and components of HRH interventions. However, we found studies related to education, policies, and those with multiple combined interventions.

\section{Education (training/task shifting)}

We identified 15 low- to moderate-quality studies. Of these, four were RCTs [30-33], eight were prospective (before/after) [34-41], two were quasi-experimental
[42, 43], and one was a prospective cohort [44]. Most of these were from African and South East Asian regions (Table 4).

To improve access to health care and conserve scarce health resources, some countries have trained mid-level providers and other cadre of health workers to deliver health care services. A study from Turkey and the Philippines compared intrauterine device (IUD) insertion by auxiliary nurse midwives (ANMs) with physicians at teaching hospitals and found no difference in those who were referred to a specialist after insertion of IUD (RR 0.93; 95\% CI, 0.45-1.90) [31]. Similarly, in Thailand, a study compared postpartum tubal ligation by midlevel health workers and found no difference between the groups in postoperative complications (RR 2.43; 95\% CI, 0.64-9.22) [30]. In a study from Nepal, the effectiveness of administration of early medical abortion by certified nurses and auxiliary nurses was compared with doctors [33]. Similarly, in South Africa and Vietnam, they compared manual vacuum aspiration (MVA) in women performed by an ANM or doctor's assistants [32]. No significant difference in the likelihood of an incomplete abortion between groups of patients managed by ANMs and those managed by doctors (RR 0.93; 95\% CI, 0.45-1.90) was found. No differences were found in the likelihood of a complication during ( $R R$ 3.07; 95\% CI, 0.16-59.1)-or an adverse event after ( $R R$ 1.36; 95\% CI, 0.54-3.40)-the MVA.

In Malawi [44], clinical officers (COs) were trained locally to perform major emergency and elective surgery. The study found no difference in postoperative maternal health outcomes, such as fever, wound infection, need for re-operation, and maternal death, when procedures performed by $\mathrm{CO}$ were compared to medical officers (MOs) (RR 0.99; 95\% CI, 0.95-1.03). No difference was observed in stillbirth (RR 0.75 ; 95\% CI, 0.52-1.09) or neonatal death (RR 1.40; 95\% CI, 0.51-3.87). However, maternal deaths were $1.17 \%$ and $0.39 \%$ in the $\mathrm{CO}$ and MO group, respectively.

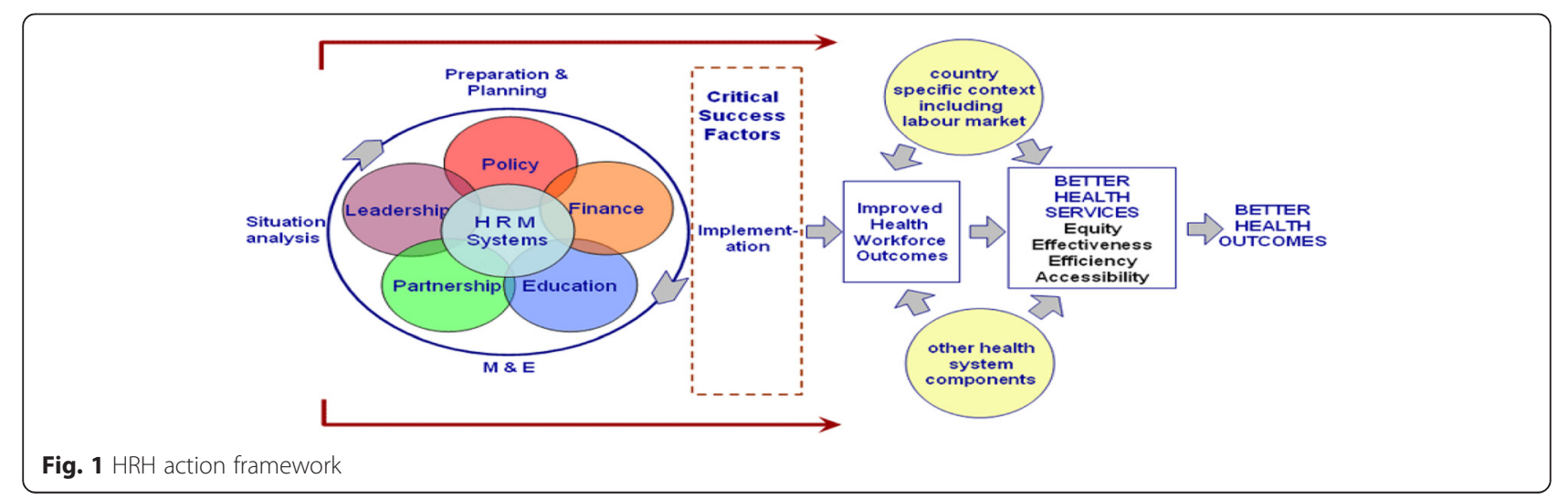


Table $3 \mathrm{HRH}$ intervention assessed

\author{
1. Management systems \\ -Personnel systems: workforce planning (including staffing norms), \\ recruitment, hiring, and deployment \\ -Work environment and conditions: employee relations, workplace \\ safety, job satisfaction, and career development Work environment \\ and conditions: employee relations, workplace safety, job satisfaction, \\ and career development \\ -HR information system integration of data sources to ensure timely \\ availability of accurate data required for planning, training, appraising, \\ and supporting the workforce \\ -Performance management: performance appraisal, supervision, and \\ productivity \\ 2. Education \\ -Pre-service education tied to health needs \\ -In-service training (e.g., distance and blended, continuing education) \\ - Capacity of training institutions \\ -Training of community health workers and non-formal care providers. \\ 3. Policy \\ -Professional standards, licensing, and accreditation \\ -Authorized scopes of practice for health cadres \\ -Political, social, and financial decisions and choices that impact $\mathrm{HRH}$ \\ -Employment law and rules for civil service and other employers \\ Source: Capacity Project [29]
}

4. Leadership

-Support HRH champions and advocates

- Capacity for leadership and management at all levels

-Capacity to lead multi-sector and sector-wide collaboration

- Strengthening professional associations to provide leadership among their constituencies

5. Partnership

-Mechanisms and processes for multi-stakeholder cooperation

(interministerial committees, health worker advisory groups, observatories, donor coordination groups)

- Public-private sector agreements

-Community involvement in care, treatment, and governance of health services

6. Finance

- Setting levels of salaries and allowances

-Budgeting and projections for $\mathrm{HRH}$ intervention resource requirements including salaries, allowances, education, incentive packages, etc.

-Increasing fiscal space and mobilizing financial resources (e.g., government, Global Fund, PEPFAR, donors)

-Data on HRH expenditures (e.g., National Health Accounts)
A study from Ethiopia [34] discussed the national program "Save the Mothers Project" that focused on providing three rounds of 3-month teaching to train service providers (general physicians (GPs), midwives, and others) on life-saving procedures in obstetrics and reported an increase in total number of instrumental deliveries from $6 \%$ in 1998 to $23 \%$ in 2001 due to considerable increase in the admission of complications. Similarly, in Bangladesh [38], MOs were trained for a year in obstetrics and anesthesia, nurses in midwifery for 6 months, and lab technicians in safe blood transfusions for a period of 2 weeks. As a result of the acquired skills, natural deliveries in the districts increased to $63 \%$, admissions of complicated cases increased to $135 \%$, and cesarean sections increased to $70 \%$. The cost per trainee was approximately $\$ 1550$ for MOs, $\$ 340$ for nurses, and $\$ 140$ for laboratory technicians.

The cost of training and deploying trained assistant medical officers (AMOs) was also compared among physicians in Mozambique [37]. They found that 30-year cost for major obstetric surgery was approximately $\$ 39$ for AMOs and \$144 for physicians. Doubling the salaries of AMOs resulted in smaller but still substantial difference in cost per surgery. Similar results were obtained from a study conducted in Tanzania [39], which started training AMOs for cesarean sections and other emergency surgeries in 1963. As a result, the met need increased and case fatality rate (CFR) decreased. There were no differences in outcomes, risk indicators, or quality of care in obstetric operations performed by AMOs and MOs.

A different approach was taken in studies conducted in Mozambique [43]. AMOs with previous surgical experience were trained for 3 years and were compared to obstetricians [43]. The only significant difference observed between the two groups was in superficial wound separation due to hematoma, which was slightly higher in AMOs (0.35\%) versus the specialists (0.05\%). Similarly, Nigeria [36] in 1993 trained midwives and residents with principles and practices of EmOC and

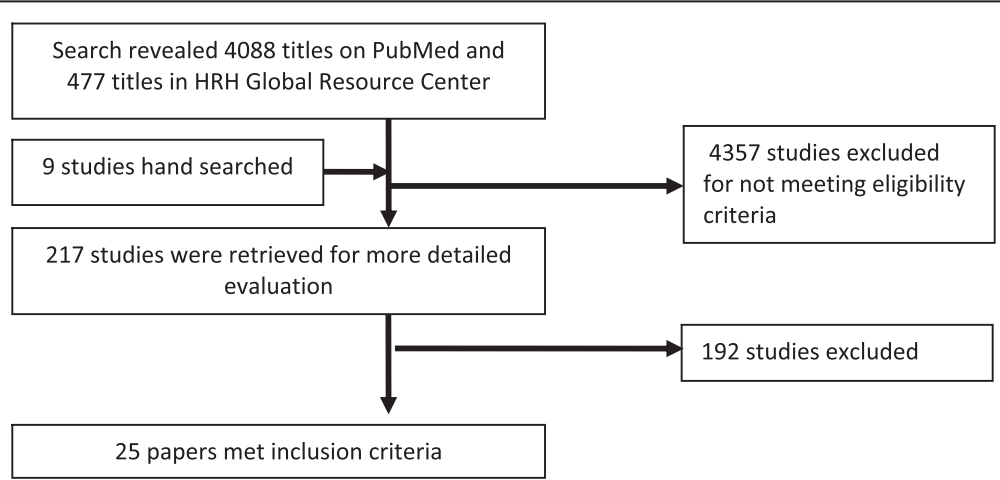

Fig. 2 Conceptual framework of HRH interventions for improved maternal outcomes 
Table 4 Studies related to HRH interventions: training and task shifting

\begin{tabular}{|c|c|c|c|c|c|c|c|c|c|c|}
\hline $\begin{array}{l}\text { Study, year } \\
\text { and type }\end{array}$ & $\begin{array}{l}\text { Type of training/ } \\
\text { intervention }\end{array}$ & $\begin{array}{l}\text { Duration of } \\
\text { training }\end{array}$ & $\begin{array}{l}\text { Time } \\
\text { between } \\
\text { intervention } \\
\text { and } \\
\text { evaluation }\end{array}$ & $\begin{array}{l}\text { Task performed } \\
\text { by }\end{array}$ & Trained by & $\begin{array}{l}\text { Area of } \\
\text { intervention } \\
\text { observed }\end{array}$ & $\begin{array}{l}\text { Other } \\
\text { interventions/ } \\
\text { tasks }\end{array}$ & Effects of training/results & Cost of training & $\begin{array}{l}\text { Quality of } \\
\text { study }\end{array}$ \\
\hline \multirow[t]{4}{*}{$\begin{array}{l}\text { Dusitsin [30] } \\
\text { Thailand RCT }\end{array}$} & \multirow[t]{4}{*}{$\begin{array}{l}\text { Tubal ligation in } \\
\text { healthy women }\end{array}$} & \multirow[t]{4}{*}{-} & \multirow[t]{4}{*}{-} & \multirow[t]{4}{*}{$\begin{array}{l}\text { Midlevel health } \\
\text { workers }\end{array}$} & \multirow[t]{4}{*}{-} & \multirow[t]{4}{*}{$\begin{array}{l}\text { Operating } \\
\text { theaters }\end{array}$} & \multirow[t]{4}{*}{-} & \multirow{4}{*}{$\begin{array}{l}\text { No difference was } \\
\text { found between the } \\
\text { groups in } \\
\text { postoperative } \\
\text { complications (RR } \\
2.43 ; 95 \% \mathrm{Cl} \text {, 0.64- } \\
9.22 \text { ). }\end{array}$} & \multirow[t]{4}{*}{-} & $\begin{array}{l}\text { Selection = } \\
\text { UR }\end{array}$ \\
\hline & & & & & & & & & & $\begin{array}{l}\text { Performance } \\
\text { and } \\
\text { detection = } \\
\text { UR }\end{array}$ \\
\hline & & & & & & & & & & $\begin{array}{l}\text { Attrition = } \\
\text { UR }\end{array}$ \\
\hline & & & & & & & & & & $\begin{array}{l}\text { Reporting }= \\
L R\end{array}$ \\
\hline \multirow{4}{*}{$\begin{array}{l}\text { Eren [31] } \\
\text { Philippines } \\
\text { and Turkey } \\
\text { controlled } \\
\text { trial }\end{array}$} & \multirow{4}{*}{$\begin{array}{l}\text { Intrauterine } \\
\text { device insertion } \\
\text { by auxiliary nurse } \\
\text { midwives }\end{array}$} & \multirow[t]{4}{*}{-} & \multirow[t]{4}{*}{-} & \multirow[t]{4}{*}{$\begin{array}{l}\text { Auxiliary nurse } \\
\text { midwives }\end{array}$} & \multirow[t]{4}{*}{-} & \multirow[t]{4}{*}{$\begin{array}{l}\text { Teaching } \\
\text { hospitals }\end{array}$} & \multirow[t]{4}{*}{-} & \multirow{4}{*}{$\begin{array}{l}\text { No difference was } \\
\text { seen in those who } \\
\text { were referred to a } \\
\text { specialist after } \\
\text { insertion of an } \\
\text { intrauterine device } \\
\text { (RR 0.93; } 95 \% \text { Cl, } \\
0.45-1.90 \text { ). }\end{array}$} & & $\begin{array}{l}\text { Selection = } \\
\text { UR }\end{array}$ \\
\hline & & & & & & & & & & $\begin{array}{l}\text { Performance } \\
\text { and } \\
\text { detection = } \\
\text { UR }\end{array}$ \\
\hline & & & & & & & & & & $\begin{array}{l}\text { Attrition }= \\
\text { UR }\end{array}$ \\
\hline & & & & & & & & & & $\begin{array}{l}\text { Reporting = } \\
L R\end{array}$ \\
\hline \multirow{5}{*}{$\begin{array}{l}\text { Warriner [32] } \\
\text { South Africa } \\
\text { and Viet Nam } \\
\text { RCT }\end{array}$} & \multirow{5}{*}{$\begin{array}{l}\text { Manual vacuum } \\
\text { aspiration } \\
\text { performed by a } \\
\text { midlevel health } \\
\text { worker, with a } \\
\text { follow-up } 10 \text { to } \\
14 \text { days later. }\end{array}$} & \multirow[t]{5}{*}{-} & \multirow[t]{5}{*}{-} & \multirow{5}{*}{$\begin{array}{l}\text { Midwives and } \\
\text { doctor's } \\
\text { assistants }\end{array}$} & \multirow[t]{5}{*}{-} & \multirow[t]{5}{*}{ Primary care } & \multirow[t]{5}{*}{-} & \multirow{5}{*}{$\begin{array}{l}\text { Manual vacuum } \\
\text { aspiration was } \\
\text { significantly greater } \\
\text { with auxiliary nurse } \\
\text { midwives. }\end{array}$} & & $\begin{array}{l}\text { Selection }= \\
\mathrm{LR}\end{array}$ \\
\hline & & & & & & & & & & $\begin{array}{l}\text { Performance } \\
=L R\end{array}$ \\
\hline & & & & & & & & & & $\begin{array}{l}\text { Detection }= \\
\text { UR }\end{array}$ \\
\hline & & & & & & & & & & Attrition $=L R$ \\
\hline & & & & & & & & & & $\begin{array}{l}\text { Reporting = } \\
L R\end{array}$ \\
\hline \multirow[t]{4}{*}{$\begin{array}{l}\text { Warriner [33] } \\
\text { Nepal RCT }\end{array}$} & \multirow{4}{*}{$\begin{array}{l}\text { Administration of } \\
\text { early medical } \\
\text { abortion }\end{array}$} & \multirow[t]{4}{*}{-} & \multirow[t]{4}{*}{-} & \multirow{4}{*}{$\begin{array}{l}\text { Certified nurses } \\
\text { and auxiliary } \\
\text { nurses }\end{array}$} & \multirow[t]{4}{*}{-} & \multirow[t]{4}{*}{ Primary care } & $\begin{array}{l}\text { Midlevel } \\
\text { health workers }\end{array}$ & $\begin{array}{l}\text { There was no } \\
\text { significant difference }\end{array}$ & - & $\begin{array}{l}\text { Selection = } \\
\mathrm{LR}\end{array}$ \\
\hline & & & & & & & $\begin{array}{l}\text { had full } \\
\text { responsibility } \\
\text { for the }\end{array}$ & $\begin{array}{l}\text { in the likelihood of } \\
\text { an incomplete } \\
\text { abortion between }\end{array}$ & & $\begin{array}{l}\text { Performance } \\
=L R\end{array}$ \\
\hline & & & & & & & $\begin{array}{l}\text { management } \\
\text { of each case. }\end{array}$ & $\begin{array}{l}\text { groups of patients } \\
\text { managed by }\end{array}$ & & $\begin{array}{l}\text { Detection = } \\
\text { UR }\end{array}$ \\
\hline & & & & & & & & $\begin{array}{l}\text { auxillary nurse } \\
\text { midwives and those } \\
\text { managed by doctors }\end{array}$ & & Attrition $=L R$ \\
\hline
\end{tabular}


Table 4 Studies related to HRH interventions: training and task shifting (Continued)

\begin{tabular}{|c|c|c|c|c|c|c|c|c|c|c|}
\hline & & & & & & & & $\begin{array}{l}\text { (RR: 0.93; } 95 \% \mathrm{Cl}, 0.45 \\
-1.90) \text {. Nor was the } \\
\text { likelihood of a } \\
\text { complication during } \\
\text { (RR: 3.07; } 95 \% \mathrm{Cl}, 0 \text {. } \\
\text { 16-59.1)—or an } \\
\text { adverse event after } \\
\text { (RR: 1.36; } 95 \% \mathrm{Cl} \text {, } \\
\text { 0.54-3.40) }\end{array}$ & & $\begin{array}{l}\text { Reporting }= \\
\text { LR }\end{array}$ \\
\hline \multirow{4}{*}{$\begin{array}{l}\text { Mekbib [34] } \\
\text { Ethiopia } \\
\text { prospective } \\
\text { (before/after) }\end{array}$} & \multirow{4}{*}{$\begin{array}{l}\text { This training } \\
\text { focused on life- } \\
\text { saving proce- } \\
\text { dures in obstetric } \\
\text { emergencies (C- } \\
\text { sections, hysterec- } \\
\text { tomies including } \\
\text { management of } \\
\text { incomplete abor- } \\
\text { tion, post abor- } \\
\text { tion scare, and } \\
\text { ectopic } \\
\text { pregnancy). }\end{array}$} & \multirow{4}{*}{$\begin{array}{l}3 \text { rounds of } \\
\text { training were } \\
\text { conducted. Each } \\
\text { for } 3 \text { months } \\
\text { period }\end{array}$} & \multirow{4}{*}{$\begin{array}{l}\text { Interventions } \\
\text { began in } \\
1999 \text {, and the } \\
\text { results were } \\
\text { analyzed in } \\
2001 .\end{array}$} & \multirow{4}{*}{$\begin{array}{l}\text { GPs, midwives, } \\
\text { and other } \\
\text { service } \\
\text { providers in } \\
\text { EmOC }\end{array}$} & \multirow{4}{*}{$\begin{array}{l}\text { Department } \\
\text { of obs/gyne } \\
\text { and master } \\
\text { trainers }\end{array}$} & \multirow{4}{*}{$\begin{array}{l}\text { Gandhi } \\
\text { Memorial } \\
\text { hospital in } \\
\text { Addis Ababa } \\
\text { and Ambo } \\
\text { hospital }\end{array}$} & $\begin{array}{l}\text { Management } \\
\text { and } \\
\text { coordination }\end{array}$ & \multirow{4}{*}{$\begin{array}{l}\text { The total number of } \\
\text { deliveries at hospital } \\
\text { increased by } 39.7 \% \\
\text { from the baseline } \\
\text { when compared } \\
\text { with the year } 2001 \text {. } \\
\text { Instrumental deliveries } \\
\text { increased from } 6 \% \text { in } \\
1998 \text { to } 23 \% \text { in } 2001 . \\
\text { The CFR for } 1999 \text { was } \\
7.2 \% \text { based on } 18 \\
\text { deaths and for } 2001 \\
\text { was } 4.6 \% \text { based on } \\
20 \text { deaths. }\end{array}$} & \multirow[t]{4}{*}{$\begin{array}{l}\text { Almost } \$ 100 \\
000 \text { was used }\end{array}$} & \multirow{4}{*}{$\begin{array}{l}1 Y, 2 Y, 3 Y, \\
4 Y, 5 Y, 6 Y, \\
7 Y, 8 Y, 9 N, \\
10 N, 11 U, \\
12 Y\end{array}$} \\
\hline & & & & & & & $\begin{array}{l}\text { Equipment, } \\
\text { supplies, and } \\
\text { drugs }\end{array}$ & & & \\
\hline & & & & & & & $\begin{array}{l}\text { Record } \\
\text { keeping }\end{array}$ & & & \\
\hline & & & & & & & Blood supply & & & \\
\hline \multirow{4}{*}{$\begin{array}{l}\text { Djan [35] } \\
\text { Ghana } \\
\text { prospective } \\
\text { (before/after) }\end{array}$} & \multirow{4}{*}{$\begin{array}{l}\text { Midwife was } \\
\text { trained in } \\
\text { vacuum } \\
\text { extraction, } \\
\text { manual removal } \\
\text { or retained } \\
\text { placenta, and } \\
\text { suturing of } \\
\text { episiotomies and } \\
\text { lacerations. } \\
\text {-MOs were } \\
\text { trained to } \\
\text { manage obstetric } \\
\text { emergencies. }\end{array}$} & \multirow[t]{4}{*}{2 weeks training } & \multirow{4}{*}{$\begin{array}{l}\text { Intervention } \\
\text { implemented } \\
1993 \text { and } \\
1994 \text { and } \\
\text { evaluated in } \\
1995\end{array}$} & \multirow{4}{*}{$\begin{array}{l}\text { Midwives and } \\
\text { medical } \\
\text { officers }\end{array}$} & & \multirow{4}{*}{$\begin{array}{l}\text { Koforidua, } \\
\text { Ghana, and } \\
\text { tertiary } \\
\text { hospital KATH }\end{array}$} & $\begin{array}{l}\text { OT, blood } \\
\text { bank }\end{array}$ & \multirow{4}{*}{$\begin{array}{l}\text { The number of } \\
\text { women with } \\
\text { complications coming } \\
\text { increased from } 26 \text { in } \\
1993 \text { to } 73 \text { in } 1995 \text {, and } \\
\text { the proportion of these } \\
\text { who were referred for } \\
\text { treatment dropped } \\
42-14 \% \text {. Surgical } \\
\text { obstetric procedures } \\
\text { performed increased } \\
\text { from } 23 \text { to 90. Midwives } \\
\text { performed 32\% manual } \\
\text { removal, 58\% vacuum } \\
\text { extractions, and } 98 \% \\
\text { episiotomy repairs. No } \\
\text { death occurred. }\end{array}$} & \multirow{4}{*}{$\begin{array}{l}\text { US\$ } 30000 \text { but } \\
\text { mostly for } \\
\text { equipment and } \\
\text { supplies }\end{array}$} & \multirow{4}{*}{$\begin{array}{l}1 Y, 2 Y, 3 Y, \\
4 Y, 5 Y, 6 N, \\
7 Y, 8 Y, 9 N, \\
10 N, 11 Y, \\
12 Y\end{array}$} \\
\hline & & & & & & & $\begin{array}{l}\text { Maternity } \\
\text { refurbished }\end{array}$ & & & \\
\hline & & & & & & & $\begin{array}{l}\text { Revolving } \\
\text { drug fund. } \\
\text { Running water } \\
\text { supply }\end{array}$ & & & \\
\hline & & & & & & & $\begin{array}{l}\text { Improving } \\
\text { access and } \\
\text { reducing delay } \\
\text { to care }\end{array}$ & & & \\
\hline $\begin{array}{l}\text { Ifenne [36] } \\
\text { Nigeria } \\
\text { prospective } \\
\text { (before/after) }\end{array}$ & $\begin{array}{l}\text { In-house training } \\
\text { of midwives and } \\
\text { residents in } \\
\text { principles and } \\
\text { practices of } \\
\text { EmOC }\end{array}$ & & $\begin{array}{l}\text { Intervention } \\
\text { started in } \\
\text { 1993, and } \\
\text { results were } \\
\text { analyzed on } \\
1994 \text { and } \\
1995 .\end{array}$ & $\begin{array}{l}\text { Midwives and } \\
\text { residents }\end{array}$ & & $\begin{array}{l}\text { Ahmadu Bello } \\
\text { University } \\
\text { Teaching } \\
\text { Hospital }\end{array}$ & $\begin{array}{l}\text {-OT restored } \\
\text {-Maternity } \\
\text { ward } \\
\text { renovated } \\
\text {-Improved } \\
\text { access and } \\
\text {-reduced } \\
\text { delay to care } \\
\text {-Blood bank } \\
\text { and drug pack } \\
\text { system }\end{array}$ & $\begin{array}{l}\text { Admission to treatment } \\
\text { interval was reduced } \\
\text { from } 3.7 \mathrm{~h} \text { to } 1.6 \mathrm{~h} \text {. } \\
\text { Proportion of women } \\
\text { treated in less than } 30 \\
\text { min increased from } \\
39 \% \text { to } 87 \% \text {. CFR fell from } \\
14 \% \text { to } 11 \% \text {. The annual } \\
\text { number of women with } \\
\text { complication declined } \\
\text { from } 326 \text { to } 65 .\end{array}$ & US\$ 135000 & $\begin{array}{l}1 Y, 2 Y, 3 Y, \\
4 Y, 5 Y, 6 U, \\
7 Y, 8 Y, 9 N, \\
10 N, 11 U, \\
12 Y\end{array}$ \\
\hline
\end{tabular}


Table 4 Studies related to HRH interventions: training and task shifting (Continued)

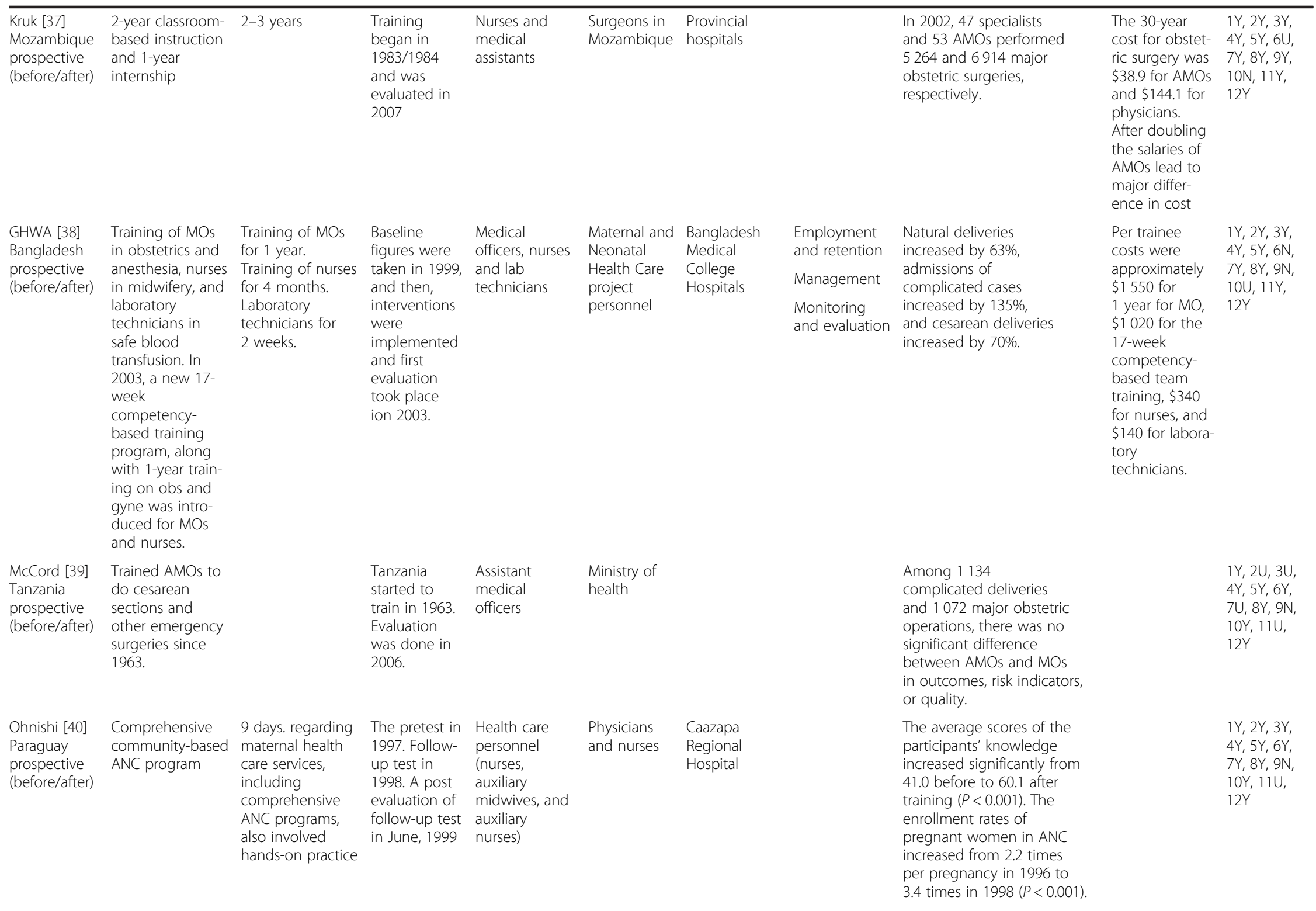


Table 4 Studies related to HRH interventions: training and task shifting (Continued)

\begin{tabular}{|c|c|c|c|c|c|c|}
\hline $\begin{array}{l}\text { Rana [41] } \\
\text { Nepal } \\
\text { prospective } \\
\text { (before/after) }\end{array}$ & $\begin{array}{l}\text { Comprehensive } \\
\text { EmOC specifically } \\
\text { for C-section and } \\
\text { other surgical } \\
\text { procedures was } \\
\text { provided to jun- } \\
\text { ior doctors. } \\
\text { BEmOC and post } \\
\text { abortion care to } \\
\text { nurses, as well as } \\
\text { anesthetic ser- } \\
\text { vices to nurses, } \\
\text { health assistants, } \\
\text { and senior auxil- } \\
\text { iary health } \\
\text { workers }\end{array}$ & $\begin{array}{l}\text { Varied from } \\
5 \text { days to } \\
6 \text { months } \\
\text { depending on } \\
\text { the type of } \\
\text { training }\end{array}$ & $\begin{array}{l}\text { Started in } \\
2000 \text { and the } \\
\text { first } \\
\text { assessment } \\
\text { was done in } \\
2001 \text { and the } \\
\text { program } \\
\text { lasted for } \\
4 \text { years till } \\
2004 \text {. }\end{array}$ & $\begin{array}{l}\text { Doctors, } \\
\text { nurses, AWH, } \\
\text { ANM, medical } \\
\text { officers, lab } \\
\text { technicians, } \\
\text { peons }\end{array}$ & $\begin{array}{l}\text { Senior } \\
\text { doctors used } \\
\text { clinical } \\
\text { training and } \\
\text { curriculum } \\
\text { for EmOC } \\
\text { developed } \\
\text { by JHPIEGO } \\
\text { and AMDD }\end{array}$ & Hospitals \\
\hline $\begin{array}{l}\text { Population } \\
\text { council [42] } \\
\text { Ghana quasi- } \\
\text { experimental }\end{array}$ & $\begin{array}{l}\text { Self-paced } \\
\text { learning (SPL) } \\
\text { course and the 3- } \\
\text { week residential } \\
\text { course. Both } \\
\text { courses covered } \\
\text { theoretical and } \\
\text { clinical training in } \\
\text { life-saving skills, } \\
\text { obstetric and in- } \\
\text { fant care, family } \\
\text { planning counsel- } \\
\text { ing, and post } \\
\text { abortion care. }\end{array}$ & $\begin{array}{l}40 \text { providers } \\
\text { (midwives and } \\
\text { physicians) in the } \\
\text { experimental } \\
\text { group received } \\
6 \text { months of SPL } \\
\text { and a 1-week } \\
\text { residential train- } \\
\text { ing course. In the } \\
\text { comparison } \\
\text { group, } 35 \text { pro- } \\
\text { viders attended } \\
\text { the 3-week resi- } \\
\text { dential course. }\end{array}$ & $\begin{array}{l}\text { Implantation } \\
\text { started in } \\
2001 \text { and } \\
\text { continued till } \\
\text { 2004. Analysis } \\
\text { was done } \\
\text { during this } \\
\text { period. }\end{array}$ & $\begin{array}{l}\text { Midwives and } \\
\text { physicians }\end{array}$ & & $\begin{array}{l}2 \\
\text { administrative } \\
\text { regions in } \\
\text { northern } \\
\text { Ghana }\end{array}$ \\
\hline $\begin{array}{l}\text { Vaz [43] } \\
\text { Mozambique } \\
\text { quasi- } \\
\text { experimental }\end{array}$ & $\begin{array}{l}\text { Assistant medical } \\
\text { officers with } \\
\text { previous } \\
\text { experience of } \\
\text { surgical work } \\
\text { were trained for } \\
3 \text { years. }\end{array}$ & 3 years & $\begin{array}{l}\text { The AMOs } \\
\text { were trained } \\
\text { in 1992, and } \\
\text { the } \\
\text { evaluation } \\
\text { took place in } \\
1996 \text {. }\end{array}$ & $\begin{array}{l}\text { Assistant } \\
\text { medical } \\
\text { officers }\end{array}$ & $\begin{array}{l}\text { Ministry of } \\
\text { health }\end{array}$ & \\
\hline
\end{tabular}

\begin{tabular}{|c|c|c|c|}
\hline \multirow{2}{*}{$\begin{array}{l}\text { Infrastructure } \\
\text { improvements } \\
\text { Data } \\
\text { collection }\end{array}$} & \multirow{4}{*}{$\begin{array}{l}\text { In } 5 \text { years, } 3 \text { comprehensive } \\
\text { and } 4 \text { basic EmOC facilities } \\
\text { were established in an area } \\
\text { where adequate EmOC } \\
\text { services were previously } \\
\text { lacking. From } 2000 \text { to } 2004 \text {, } \\
\text { met need for EmOC } \\
\text { improved from } 1.9 \% \text { to } \\
16.9 \% \text {; the proportion of } \\
\text { births in EmOC project } \\
\text { facilities increased from } \\
3.8 \% \text { to } 8.3 \% \text {; and the case } \\
\text { fatality rate declined from } \\
2.7 \% \text { to } 0.3 \% \text {. }\end{array}$} & \multirow{4}{*}{$\begin{array}{l}\text { Technical } \\
\text { training US\$ } \\
205660 \\
\text { Management } \\
\text { training US\$97 } \\
170\end{array}$} & \multirow{4}{*}{$\begin{array}{l}1 Y, 2 Y, 3 Y, \\
4 Y, 5 Y, 6 U, \\
7 Y, 8 Y, 9 N, \\
10 N, 11 Y, \\
12 Y\end{array}$} \\
\hline & & & \\
\hline Equipment & & & \\
\hline \multirow[t]{8}{*}{$\begin{array}{l}\text { Policy } \\
\text { advocacy and } \\
\text { community } \\
\text { information } \\
\text { activities }\end{array}$} & & & \\
\hline & \multirow{4}{*}{$\begin{array}{l}\text { Knowledge improved in } \\
\text { (SLP) group following the } \\
\text { intervention, while clinical } \\
\text { performance improved in } \\
\text { both groups, with the } \\
\text { residential group performing } \\
\text { slightly better. Mean scores } \\
\text { for management of obs } \\
\text { complications, PAC, and } \\
\text { pregnancy-related } \\
\text { complications improved } \\
\text { significantly in the SPL group. }\end{array}$} & \multirow{4}{*}{$\begin{array}{l}\text { The self-paced } \\
\text { learning ap- } \\
\text { proach cost } \\
\text { more per } \\
\text { learner than } \\
\text { the residential } \\
\text { course (US\$2 } \\
154 \text { versus US\$ } \\
1330 \text { ). }\end{array}$} & $\begin{array}{l}\text { Selection = } \\
\text { UR }\end{array}$ \\
\hline & & & $\begin{array}{l}\text { Performance } \\
\text { and } \\
\text { detection = } \\
\text { UR }\end{array}$ \\
\hline & & & $\begin{array}{l}\text { Attrition = } \\
\text { UR }\end{array}$ \\
\hline & & & $\begin{array}{l}\text { Reporting = } \\
L R\end{array}$ \\
\hline & \multirow{3}{*}{$\begin{array}{l}\text { No difference in indication } \\
\text { for cesarean deliveries. The } \\
\text { only significant difference was } \\
\text { in the group of superficial } \\
\text { wound separation which was } \\
\text { slightly more ( } 0.35 \% \text { vs } 0.05 \%) \\
\text { in AMO vs specialist group. }\end{array}$} & & $\begin{array}{l}\text { Selection = } \\
\text { UR }\end{array}$ \\
\hline & & & $\begin{array}{l}\text { Performance } \\
\text { and } \\
\text { detection = } \\
\text { UR }\end{array}$ \\
\hline & & & $\begin{array}{l}\text { Attrition = } \\
\text { UR }\end{array}$ \\
\hline
\end{tabular}

UR

Reporting = 
Table 4 Studies related to HRH interventions: training and task shifting (Continued)

\begin{tabular}{|c|c|c|c|c|c|c|c|c|}
\hline $\begin{array}{l}\text { Chilopora } \\
\text { [44] Malawi } \\
\text { prospective } \\
\text { cohort study }\end{array}$ & $\begin{array}{l}\text { COs were trained } \\
\text { locally for } 3 \text { years. }\end{array}$ & 3 years & $\begin{array}{l}\text { The } \\
\text { Government } \\
\text { of Malawi has } \\
\text { been training } \\
\text { clinical } \\
\text { officers since } \\
1974 \text {. }\end{array}$ & Clinical officers & $\begin{array}{l}\text { Government } \\
\text { of Malawi }\end{array}$ & $\begin{array}{l}\text { After a 1-year } \\
\text { internship, } \\
\text { they were li- } \\
\text { censed to } \\
\text { practice } \\
\text { independently. }\end{array}$ & $\begin{array}{l}\text { No significant difference in } \\
\text { postoperative maternal health } \\
\text { outcomes, after emergency } \\
\text { obstetric procedures } \\
\text { performed by CO or by } \\
\text { medical officers (RR 0.99; } 95 \% \\
\text { Cl, } 0.95-1.03 \text { ). No significant } \\
\text { difference in stillbirth with } \\
\text { procedures performed by CO } \\
\text { (RR } 0.75 ; 95 \% \mathrm{Cl}, 0.52-1.09 \text { ) or } \\
\text { in early neonatal death (RR: } \\
1.40 ; 95 \% \mathrm{Cl}, 0.51-3.87) \text { ). } \\
\text { Although } 22 \text { maternal deaths } \\
\text { occurred in } 1875 \text { procedures } \\
\text { performed by CO compared } \\
\text { with } 1 \text { in } 256 \text { procedures } \\
\text { performed by medical } \\
\text { officers. }\end{array}$ & $\begin{array}{l}1 Y, 2 Y, 3 Y, \\
4 Y, 5 U, 6 U, \\
7 Y, 8 Y, 9 Y, \\
10 N, 11 U, \\
12 Y\end{array}$ \\
\hline
\end{tabular}


henceforth found a reduction in treatment interval from $3.7 \mathrm{~h}$ to $1.6 \mathrm{~h}$, and the proportion of women treated in less than $30 \mathrm{~min}$ increased from $39 \%$ to $87 \%$. CFR fell from $14 \%$ to $11 \%$. The annual number of women with complication declined as well.

Nepal, on the other hand, trained doctors, midwives, and nurses on different aspects of basic and comprehensive EmOC services [41] and found a reduction in CFR from $3.0 \%$ to $0.3 \%$. Similarly, in Paraguay [40], nurses, auxiliary nurses, and auxiliary midwives were trained on theoretical and clinical aspects of life-saving skills in obstetric emergencies and reported an increase in knowledge. A study from Ghana [42] provided 6 months of self-paced and 1-week of residential training to midwives and physicians and compared them to a similar cadre given 3-week residential training on life-saving skills, obstetric and infant care, family planning counseling, and post abortion care. The residential group performed slightly better; however, overall levels of knowledge and performance remained low.

\section{Policy implementation}

We identified four moderate-quality [12, 45-47] prospective before/after studies (Table 5).

In the beginning of 1994, Bangladesh upgraded its EmOC facilities and trained service providers in those facilities [46]. However, from the beginning of 2001, to complement the facility approach to obstetric care, a skilled birth attendant strategy was initiated with guidance from the World Health Organization and UNFPA. As a result, measles, mumps, and rubella (maternal mortality ratio (MMR)) declined to $22 \%$ in the 11 intervening years. Professional care increased from $13 \%$ to $18 \%$ and rates of cesarean section from $0.9 \%$ to $5.4 \%$. The policy implementation also affected the antenatal consultation which doubled from $27 \%$ in 1991-1994 to 60\% in 2005-2007.

Similarly, the Nepal National Safe Motherhood Project [47], implemented from 1997 to 2004, focused on improving emergency obstetric services and midwifery care in selected health facilities. Government policy was developed to increase access to midwifery and obstetric services to improve management of service provision for women of reproductive age by working with NGOs for training and service provision and non-state health workers. As a result, the average annual met need increased from $1.3 \%$ to $14 \%$. Deliveries attended by ANMs or nurse increased from 3\% in 2001 to $8 \%$ in 2006. Free or reduced cost for services and transport was valued by the communities, and the intervention increased their confidence to cope with emergencies.

In Cambodia, to compensate low wages, health care workers demanded unofficial payments from patients in facilities where health care services were provided free of charge. Introduction of a user fee at the national maternal and child health center of Cambodia [45] assisted the hospital to retain revenue and improve the quality of services focusing on the work environment and conditions of HR intervention. Patient satisfaction increased to $93 \%$, and average monthly number of deliveries increased from 319 to 585 .

The Indonesian government in order to overcome the shortage of health workers [12] implemented compulsory services in rural areas to support the recruitment and deployment of medical staff in remote and very remote areas. Doctors, dentists, and midwives were assigned as temporary staff on contract basis for a certain time. In addition, a special assignment program was implemented which included other health cadres as well where they received travel expenses and additional incentives for a period of service and according to the remoteness. Both these programs improved the availability of health workers in remote areas. As a result, in 2010, only $17 \%$ of the 9000 very remote health centers were without a doctor, compared with $30 \%$ of 8000 health centers in 2006.

\section{Combined interventions}

We found six low- to moderate-quality prospective before/after studies [24, 48-52] with combined interventions which focused on HR training, policy and advocacy, partnerships, and supervision [49] (Table 6).

In one study from Rwanda [50], CARE's work supported a comprehensive package of interventions which included training of the doctors and midwives to manage major obstetric complications. As a result, numbers of deliveries and management of obstetric complications increased by almost $25 \%$ and $27 \%$, respectively, from 2001 to 2002. A continuous decrease in the CFR was also observed from $2.2 \%$ in 2001 to $1.8 \%$ in 2002 and finally $1.2 \%$ in 2004 .

Similarly, in Peru [51], a decline in CFR from $1.7 \%$ to $0.1 \%$ and increase in met needs from $30 \%$ to $84 \%$ were observed after the implementation of a 15-day training and supervision program to improve the quality of care. Likewise, Mozambique [52] trained 137 different professionals and adopted an enhanced policy for the improvement of the quality, access, and utilization of the EmOC such as supportive supervision, logistics for supplies, provision of equipment and drugs, record keeping, monitoring and evaluation, and quality improvement techniques. Maternal death audits showed an increase in met needs from $11 \%$ to $33 \%$ and decrease in CFR from $3 \%$ to $1.6 \%$. Similarly, in Nepal [24], utilization of antenatal care services increased from 39\% to $72 \%$, delivery by trained SBAs from $9 \%$ to $19 \%$, institutional delivery from $8 \%$ to $18 \%$, cesarean sections from $1 \%$ to $3 \%$, and CFR decreased from $0.5 \%$ to $0.4 \%$ after the establishment of policy to provide EmOC to the most deprived 
Table 5 Studies related to HRH intervention: policy

\begin{tabular}{|c|c|}
\hline Study & Policy implemented \\
\hline $\begin{array}{l}\text { Efendi [12] Indonesia } \\
\text { program evaluation } \\
\text { (before/after) }\end{array}$ & $\begin{array}{l}\text { Doctors and dentists were assigned as } \\
\text { temporary staff on contract basis for a } \\
\text { certain time period under "Contracted } \\
\text { staff" or Pegawai Tidak Tetap (PTT) } \\
\text { policy. Similarly, in the Village Midwife } \\
\text { Program scheme, midwives were } \\
\text { assigned to rural areas. In addition to } \\
\text { the PTT scheme, the Special Assignment } \\
\text { Program for Strategic Health Workers was } \\
\text { implemented which included nurses, } \\
\text { sanitarians, nutritionists, and other health } \\
\text { cadres as well. }\end{array}$ \\
\hline
\end{tabular}

Akashi [45] Cambodia User fees introduced at a public hospital, prospective (before) after)
When
1991
Koblinsky [46] Bangladesh prospective (before) after)
In 1994, the EmOC approach dominated with assistance from the UNICEF, UNFPA and the AMDD program in the renovation and up gradation of existing facilities and training of facility staff. With the development of the National Materna Health Strategy in 2001, the approach broadened, building on the rights' approach for safer motherhood and was and Population Sector Programme (HPSP) and subsequently into the Health, Nutrition and Population Sector Programme (HNPSP)

Areas implemented on

Outcomes

Quality of the study

Remote and very remote areas (division Both these programs made a significant based on geographical position, access contribution to improving the availability to transportation and the social economy)

of health workers in remote areas. As a result, in 2010 , only $17 \%$ of the 9000 very remote health centers were without a doctor, compared with $30 \%$ of 8000 health centers in 2006

$\mathrm{MOH}$ started discussions to improve health care financing and introduce user contributions in 1995 and initiated a user-fee pilot program in selected national health facilities in 1997.

1994 and 2001 and first evaluation took place in 1995
EmOC at the facility level

CSBAs providing safe delivery care at home.
After the introduction of user fees, revenue was retained by the hospital to improve the quality of hospital services. Consequently, the patient satisfaction rate showed $92.7 \%$, and the number of outpatients doubled. The average monthly number of delivery of babies increased from 319 to 585 in the third year after the user-fee introduction, and the bed occupancy rate also increased from 50.6\% to $69.7 \%$. As patient utilization increased, hospital revenue increased. The generated revenue was used to accelerate quality improvement, to provide staff with additional fee incentives to compensate their low government salaries, and to expand hospital services.

Since 1990, the MMR in Bangladesh has declined from 514 in 1986-1990 to 400 in $2003-22 \%$ in the 11 intervening years.

Deaths from induced abortion have declined when the 1995-2005 level is compared with the pre-intervention levels of 1976-1980.

During 2000-2004, MMR was 322; only $13 \%$ of delivering-women used professional care for birthing, and $9 \%$ of births were in facilities. By 2007, 18\% were delivering with professional care and 15\% were in facilities.

For cesarean section in rural areas, the rate increased from $0.9 \%$ to $1.7 \%$ from 1995-1996 to 2000-2004 and then to $5.4 \%$ in 2005-2007, while in urban areas, the corresponding rates doubled-from
$6 \mathrm{U}, 7 \mathrm{Y}, 8 \mathrm{Y}, 9 \mathrm{~N}, 10 \mathrm{~N}$

$11 \mathrm{~N}, 12 \mathrm{Y}$ $6 \mathrm{U}, 7 \mathrm{~N}, 8 \mathrm{Y}, 9 \mathrm{U}, 10 \mathrm{~N}$ $11 \mathrm{~N}, 12 \mathrm{Y}$ 
Rath [47] Nepal

prospective (before/

after)
The Nepal National Safer Motherhood

Project was a collaborative intervention

between the Nepal Ministry of Heath

and Population and the UK

Department for International

Development (DFID), managed by

Options Consultancy Services.
1997-2004, evaluation In phase 1, the Project focused mainly was done yearly

on improving midwifery and

emergency obstetric services in selected health facilities in 3 districts and then in phase 2, to 6 districts. Two main components were developed: (i) management of service provision for women of reproductive age, including improvements to the physical infrastructure of hospitals, equipment and supplies, and training of personnel and (ii) increasing access to midwifery and obstetric services by improving the social context to enable women to utilize services.
$5.6 \%$ to $11.4 \%$ and then increased to

\section{$16.2 \%$ in $2005-2007$}

The increase in the use of antenatal

care has shown promise-from $27 \%$ in

$1991-1994$ to $60 \%$ in 2005-2007.

Met need for emergency obstetric care was $<5 \%$ in the phase 1 districts

$Y, 2 U, 3 Y, 4 Y, 5 Y$,

$6 \mathrm{U}, 7 \mathrm{Y}, 8 \mathrm{Y}, 9 \mathrm{~N}, 10 \mathrm{~N}$

$11 \mathrm{U}, 12 \mathrm{Y}$

in 1997. The average annual increase

in met need has been 1.3\% per year

over the intervention period, bringing it to the 2004 level of $14 \%$ in public sector facilities in project-supported districts. In a further 4 districts supported by UNICEF, met need

increased from $1.9 \%$ to $16.9 \%$ between 2000 to 2004.

Availability of a skilled birth attendant near the home

The 2001 Demographic and Health Survey (DHS) found that only 3.1\% of deliveries of the approximately 900000 births per annum were attended by an auxiliary nurse midwife or nurse. This had increased to $8.3 \%$ in the 2006 DHS.

Free or reduced costs for services and transport

Communities valued these funds and that they increased confidence in

being able to cope with emergencies. 
Table 6 Studies related to HRH intervention: combined interventions

\begin{tabular}{|c|c|c|c|c|c|c|c|c|c|}
\hline \multirow[t]{2}{*}{ Study } & \multicolumn{7}{|l|}{ HRH management system } & \multirow[b]{2}{*}{$\begin{array}{l}\text { Intervention } \\
\text { to evaluation } \\
\text { duration }\end{array}$} & \multirow[t]{2}{*}{ Others } \\
\hline & Training & Policy & Management & Incentive & Supervision & Partnership & Personnel system & & \\
\hline \multicolumn{10}{|l|}{$\begin{array}{l}\text { Kayongo [50] } \\
\text { Peru (before/ } \\
\text { after) }\end{array}$} \\
\hline \multirow[t]{2}{*}{ Implementation } & \multirow{2}{*}{\multicolumn{2}{|c|}{$\begin{array}{l}\text { Training sessions for } \\
15 \text { days with on-call } \\
\text { duty after an analysis } \\
\text { of the causes of mater- } \\
\text { nal death, the treat- } \\
\text { ment, and prevention } \\
\text { of postpartum } \\
\text { hemorrhage received } \\
\text { special emphasis in } \\
\text { the trainings. }\end{array}$}} & $\begin{array}{l}\text { Development of a } \\
\text { more efficient } \\
\text { mechanism for } \\
\text { recordkeeping and } \\
\text { data collection. }\end{array}$ & & \multirow{2}{*}{$\begin{array}{l}\text { Quality of care was } \\
\text { enhanced through the } \\
\text { use of criterion-based } \\
\text { audits. External sup- } \\
\text { portive supervision } \\
\text { and on-site quality im- } \\
\text { provement processes } \\
\text { were used to enhance } \\
\text { efficient service } \\
\text { delivery. }\end{array}$} & \multirow{2}{*}{$\begin{array}{l}\text { The FEMME Project } \\
\text { worked with } \\
\text { community groups to } \\
\text { form local } \\
\text { committees. CARE's } \\
\text { most important } \\
\text { partners in the } \\
\text { FEMME Project have } \\
\text { been the IMP in Lima, } \\
\text { the Ayacucho DIRESA, } \\
\text { and the Regional } \\
\text { Hospital. }\end{array}$} & & \multirow{2}{*}{$\begin{array}{l}\text { The } \\
\text { intervention } \\
\text { started in } \\
2000 \text { and the } \\
\text { first } \\
\text { evaluation } \\
\text { took place in } \\
2001 \text { and } \\
\text { then in next } \\
\text { three years till } \\
2004 \text {. }\end{array}$} & \multirow[t]{2}{*}{$\begin{array}{l}\text { Facility setup, } \\
\text { including } \\
\text { adequate } \\
\text { infrastructure, } \\
\text { equipment, and } \\
\text { supplies }\end{array}$} \\
\hline & & & $\begin{array}{l}\text { Placement of trained } \\
\text { staff to ensure a wide } \\
\text { distribution of } \\
\text { technical capability to } \\
\text { resolve obstetric } \\
\text { emergencies. }\end{array}$ & & & & & & \\
\hline
\end{tabular}

Outcomes CFR decreased from $1.7 \%$ to $.01 \%$, increase in met needs from $30 \%$ to $84 \%$ in 5 years, and a small increase in cesarean sections from $4 \%$ to $6 \%$.

Quality: 1Y, 2Y, 3Y, 4Y, 5Y, 6Y, 7Y, 8Y, 9N, 10N, 11U, 12Y

Kayongo [51]

Rwanda (before/

after)

Implementations

$\begin{array}{ll}\text { CARE conducted } & \text { Staff, including } \\ \text { several trainings to } & \text { doctors and } \\ \text { provide doctors and } & \text { midwives, were } \\ \text { midwives to manage } & \text { trained and } \\ \text { major obstetric } & \text { supported to ensure } \\ \text { complication. Most } & \text { complete recording } \\ \text { significant training } & \text { of case notes and } \\ \text { course was a 12- } & \text { filling out of registers. } \\ \text { module competency- } & \\ \text { based training } & \end{array}$

$\begin{array}{ll}\text { Main strategies of the } & \text { Stakeholders in the } \\ \text { project were to } & \text { MoH, local partners in } \\ \text { engage the } & \text { safe motherhood } \\ \text { participation of district } & \text { such as UNFPA, } \\ \text { supervisors as partners } & \text { district health officials, } \\ \text { for improving and } & \text { and hospital health } \\ \text { transforming this } & \text { professionals were } \\ \text { process. } & \text { involved in various } \\ & \text { process of the project. }\end{array}$

$\begin{array}{ll}\text { The } & \text { Renovations }\end{array}$

interventions and provision of

started in essential

2001 with first equipment and

evaluation in supplies

2002 and

then

consequently

in 2003 and based training.

Outcomes Numbers of deliveries increased by almost 25\% from 2001 to 2002, and the obstetric complications managed increased by almost the same magnitude (26.5\%). Cesarean section increased by $63 \%$ during this time. There was a continuous decrease in the case fatality rate over the 4 years of the project from $2.2 \%$ in 2001 to 1.8 in 2002 and finally $1.2 \%$ in 2004.

Quality: 1Y, 2Y, 3Y, 4Y, 5Y, 6Y, 7Y, 8Y, 9N, 10N, 11U, 12Y

Jamisse [49]

Mozambique

(before/after)

Implementations Technicians trained in

surgery and

Supervision of the

surgery and
anesthesia, nurses

activities was the
responsibility of the

trained as surgical

assistants. MNCH

Ministry of Health.

$\begin{array}{ll}\text { Intervention } & \text { Supplementing } \\ \text { started in } & \text { equipment and } \\ 1998 \text { and the } & \text { essential } \\ \text { first } & \text { supplies at the } \\ \text { evaluation } & \text { EmOC units }\end{array}$


Table 6 Studies related to HRH intervention: combined interventions (Continued)

\begin{tabular}{|c|c|c|}
\hline $\begin{array}{l}\text { nurses and midwives } \\
\text { were trained in basic } \\
\text { and comprehensive } \\
\text { EmOC and } \\
\text { management of major } \\
\text { obstetric } \\
\text { complications. }\end{array}$ & $\begin{array}{l}\text { was done in } \\
1999 \text { and } \\
\text { then } \\
\text { consequent } \\
\text { evaluations } \\
\text { for } 2 \text { more } \\
\text { vears. }\end{array}$ & $\begin{array}{l}\text { Radio } \\
\text { communication } \\
\text { and transport } \\
\text { system was } \\
\text { established }\end{array}$ \\
\hline
\end{tabular}

Outcomes

José Macamo Hospital, which dealt with 14\% of all deliveries and 2.5\% of all C-sections in 1998, was responsible for 32\% of all deliveries and 38\% of all C-sections in Maputo city in 2001. Mavalane never succeeded in providing comprehensive EmOC $24 \mathrm{~h}$ a day. It did succeed, however, in almost doubling the number of deliveries, from 2500 in 1998 to almost 5000 in 2001. While in 1998 the Manhica Hospital managed 29\% of institutional deliveries and 8.2\% of cesarean sections in the district, these percentages increased to 33\% and $31.2 \%$, respectively, in 2001. The maternal deaths per total number of deliveries occurring in the district's institutions were 572/100 000 live births in 1998 and $433 / 100000$ in 2001. The case fatality rate in basic EmOC units decreased from 4.7 in 2000 to 2.4 in the first 6 months of 2002

Quality: 1Y, 2U, 3U, 4Y, 5Y, 6U, 7U, 8Y, 9N, 10N, 11U, 12Y

Santos [52]

Mozambique

(before/after) session for basic EmOC endorsed UN process indicators consisted of 1 week of EmOC for obstetric services theory and 3 weeks of as its monitoring practical hands-on extools

perience, emergency tools

transport, and referr

system.

$\begin{array}{ll}\begin{array}{l}\text { The Medical Director } \\ \text { of the Provincial }\end{array} & \text { Mozambique was } \\ \text { Health Directorate and } & \text { UNFPA. AMDD was } \\ \text { the Chief Nurse were } & \text { supported by the Bill } \\ \text { given the } & \text { and Melinda Gates } \\ \text { responsibility to } & \text { Foundation. } \\ \text { coordinate all activities } & \\ \text { of the project, which } & \\ \text { included frequent } \\ \text { supervisory visits to } \\ \text { the facilities. }\end{array}$

Interventions Renovation of started in the hospitals, 1999, and first equipments and evaluation emergency began in drugs and 2002 and was supplies were continued for provided 3 years till 2005.

Outcomes

Utilization among women with complications (met need or the proportion of women expected to have complications who are admitted for treatment) increased 3-fold, from 11.3\% to $32.8 \%$ in all facilities. The aggregate case fatality rate (CFR) was reduced by almost half ( $2.9 \%$ to $1.6 \%$ ).

Islam [48]

Bangladesh

(before/after)

Implementations Training of medical officers was originally designed as a 6-month course but was later

extended to 1 year.

Training of nurses was extended from 6 weeks to 4 months. Laboratory technicians partici-

pated in a 2-week training course.

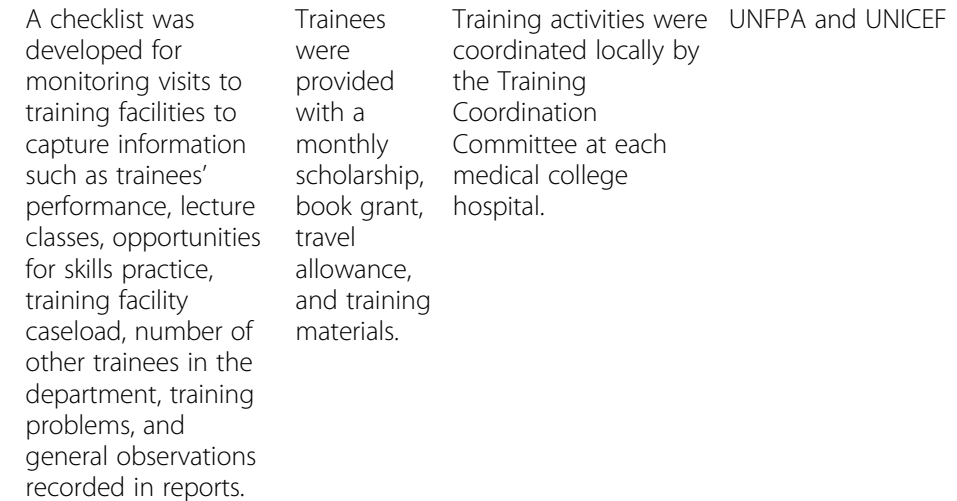

\begin{tabular}{|c|c|c|}
\hline $\begin{array}{l}\text { Manager of the } \\
\text { Directorate General } \\
\text { of Health Services } \\
\text { selected the } \\
\text { medical officers for } \\
\text { training, while } \\
\text { nurses and } \\
\text { laboratory } \\
\text { technicians were } \\
\text { selected from the } \\
\text { facilities. }\end{array}$ & $\begin{array}{l}\text { Intervention } \\
\text { started in } \\
2003 \text { and } \\
\text { evaluation } \\
\text { was done in } \\
2004 \text {. }\end{array}$ & $\begin{array}{l}\text { Supply of } \\
\text { necessary } \\
\text { equipment and } \\
\text { logistics. } \\
\text { Renovations of } \\
\text { the facilities }\end{array}$ \\
\hline
\end{tabular}


Table 6 Studies related to HRH intervention: combined interventions (Continued)

Outcomes In 2004, 105 of the 120 sub-district hospitals had become functional for EmOC, 70 with comprehensive EmOC, and 35 with basic EmOC, while 53 of 59 of the district hospitals were providing comprehensive EmOC compared to 35 in 1999

Quality: 1Y, 2Y, 3Y, 4Y, 5Y, 6Y, 7Y, 8Y, 9N, 10N, 11U, 12Y

Barker [24]

Nepal (before/

after)

Implementations

$\begin{array}{lll}\text { Ongoing work to } & \text { SSMP } & \text { SSMP } \\ \text { incorporate training for } & \text { worked with } & \text { supported } \\ \text { skilled birth attendants } & \text { other safe } & \text { Maternity } \\ \text { into pre-service } & \text { motherhood } & \text { Incentives } \\ \text { courses for doctors } & \text { stakeholders } & \\ \text { and nurses } & & \end{array}$

supported

laternity

and nurses

Utilization of antenatal care services increased from $39 \%$ to $72 \%$, delivery by a trained health worker from $9 \%$ to $19 \%$, institutional delivery from $8 \%$ to $18 \%$, and cesarean sections from $1 \%$ to $2.7 \%$. CFR decreased from $0.5 \%$ to $0.4 \%$. 
population. Incentives were given to the mothers and health workers to address the financial barriers to women accessing maternal services. A range of external agencies supported staff training; infrastructure and equipment; behavior change interventions promoting antenatal, skilled delivery, and postpartum care; and community emergency funds and transport schemes.

\section{Discussion}

A major part of this review was aimed at exploring how $\mathrm{HRH}$ interventions lead to improved maternal health outcomes, and we also came across studies with successful $\mathrm{HRH}$ strategies pertaining to general health outcomes $[12,16,18,53]$. The findings, although mostly from lowto moderate-quality studies, showed that HRH interventions can contribute positively to the health worker's performance and improved maternal outcomes. However, we still feel that $\mathrm{HRH}$ interventions in relation to maternal health are not widely researched.

The WHO framework (Fig. 1) shows the steps required for improving general health outcomes; we developed a framework to facilitate understanding of mechanisms, based upon dimensions of health worker performance (Fig. 3), to explain the effect on maternal mortality. It reveals a variety of interrelated mechanisms which can lead to improved health worker performance and maternal health outcomes provided other associated or confounding factors are addressed. Implementation of a HRH management system to improve the availability, training, education, and retention of doctors, nurses, midwives, and technicians is one of the factors contributing to improved maternal health. Other components included in the studies were supervision and partnerships which improved the health system effectiveness and hence maternal health. Increase in knowledge and competence with concomitant increase in accountability and productivity of SBAs will lead to better health outcomes resulting in decrease in maternal mortality and morbidity.

The review of 25 studies revealed certain reasons why maternal mortality and morbidity is still high in LMICs despite the efforts and policies implemented throughout these years. It is observed that in many LMICs some components of the HRH intervention were applied with positive effects on the maternal health and health care delivery to the rural areas. When a professional (doctor or midwife) is linked up with a strong referral system, maternal health outcomes improve and mortality decreases significantly irrespective of whether the birth took place at home or in a health facility [54]. Programs should therefore integrate maternal health and family planning as decline in fertility can reduce maternal mortality which can be achieved by aligning formal/informal linkages or partnering different programs [55]. Secondly,

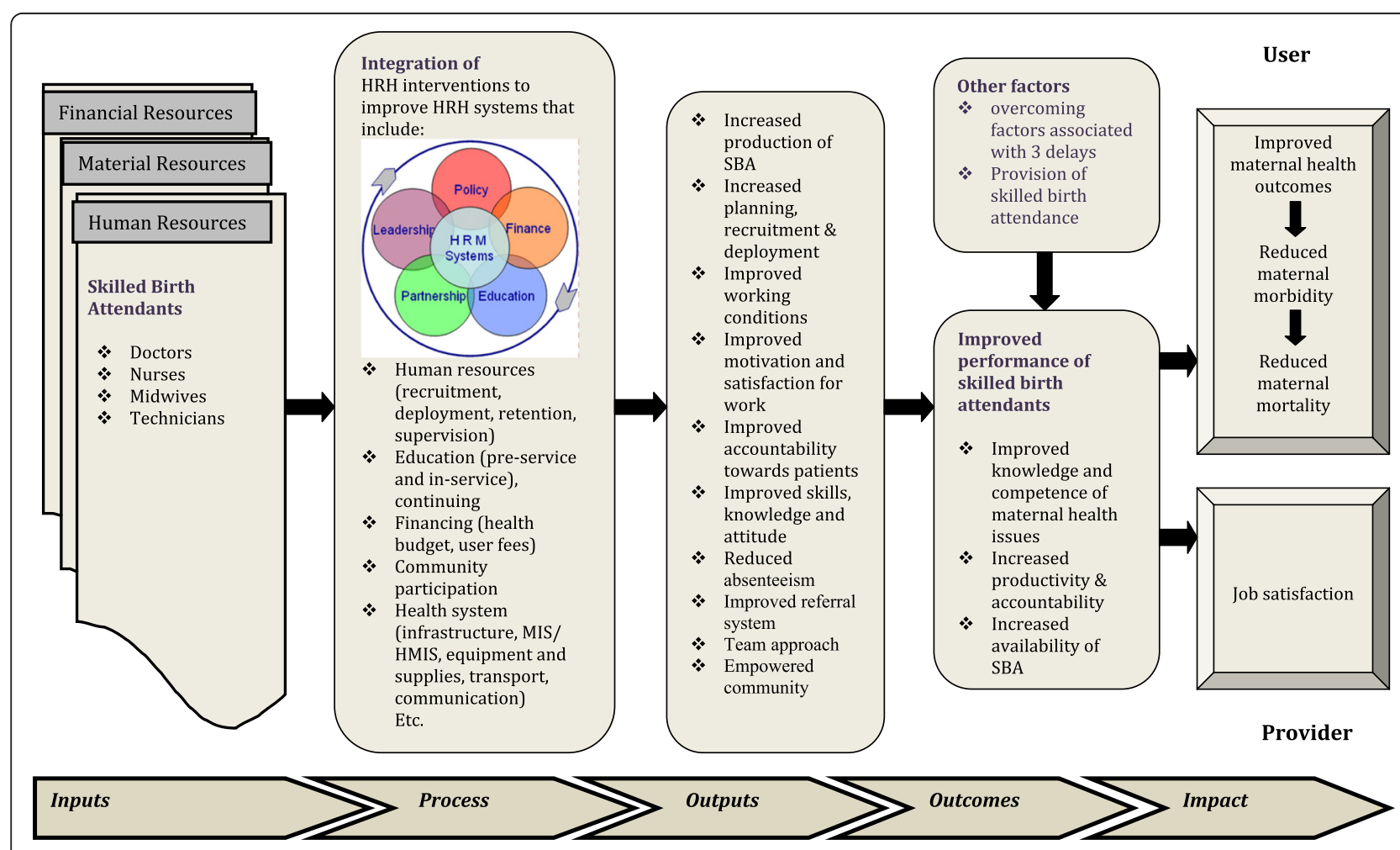

Fig. 3 Conceptual framework of HRH interventions for improved maternal outcomes 
it is important to educate women about their health and complications during pregnancy, and evidence suggests that awareness improves care seeking [55, 56]. However, poverty is one of the main factors affecting the access to maternal health care in rural areas which warrants combating gender inequalities [56, 57]. In such scenarios, community involvement has been found to be integral in raising the awareness in community which can further be scaled up to integrate micro-financing schemes to help improve the financial stability in families/ community.

In the review, we found that only few components of the HRH management system were investigated. Most of the studies explored the impact of training and continuing education of the health care providers on maternal health individually or as combined intervention. However, less or no work was found on the HRH systems studying the impact of recruitment, employment, hiring, deployment, migration, health safety, and retirement on maternal health outcomes. Similarly, no study was found on the financial component addressing the budget allocation for salaries and allowances, education and training, and HRH expenditure data. Gaps were identified in other $\mathrm{HRH}$ interventions related to staff motivations such as job satisfaction, appraisals, workplace safety, career development, and improvement in the work environment as well as the HRH information system. Moreover, studies that reported the impact of training SBAs on improved health outcomes rarely reported if those results were merely because of training alone or there was a role of other related cointerventions as well.

Improvements in $\mathrm{HRH}$ are required to be made by LMICs to raise the awareness among women for health care seeking from SBAs and at the same time improving the delivery of health care. The need for a multi-sectoral approach to women health is emphasized. This includes the training of staff, their employment and retention, and improved management systems in the formal health care [58]. It is important to address the keen desire of continued education/training of health workers especially doctors. The training and education programs implemented in some countries need to be taken on the larger scale. Also, the keen desire of health workers especially doctors embarking higher positions should be addressed. Government should work in conjunction with other stakeholders and donors to form policies for education and finance and develop health care models to suit the needs of the countries in managing EmOC and decreasing maternal mortality.

We recommend that more studies need to be conducted on the other HRH management system components such as supervision, partnership, and proper $\mathrm{HRH}$ information system development especially in the context of SBAs and their impact on the maternal health. Financial constraint remains the most important barrier to achieve the targets. Therefore, interventions targeting the budget allocations for the salaries and education of the health care providers need to be implemented and their impact on maternal mortality to be studied. It is well documented that more lives of mothers can be saved if adequate importance is given to the EmOC services and if they are made an integral part of the health system $[59,60]$. The importance of collaboration between SBAs and other health care providers like obstetricians and anesthesiologists as well as lay health providers has also been emphasized [25, 61], and its integration in national policies has also been underscored for better outcomes [58, 62-64]. Political sensitization is needed at the local level, particularly with local policies [65]. Investment at all levels to strengthen the comprehensive EmOC and family-planning program is required [55]. Political parties, stakeholders, and donors need to work together to invest in improving the availability and quality of maternal care services [56]. A high level of political commitment is also required in investing, developing, deploying, and supporting a cadre of health providers with midwifery skills [66].

It is important to assess and urgently address the barriers to recruitment, deployment, and retention of skilled personnel in LMICs [67] and to discourage the process of "brain drain" $[68,69]$. The deployment, recruitment, and retention of care providers especially nurses and specialists are a major challenge on the supply side [69-71].

Furthermore, it is important to provide health care professionals with ongoing training [72, 73]. A study from Kenya reported that only $18 \%$ of the staff had received life-saving skills and only $37 \%$ received training related to prevention of mother-to-child HIV transmission, which is the utmost required skill in a country like Africa [73]. Thus, it emphasizes the importance of training to meet the needs of the population.

The limited management capacity is one of the main reasons of slow progress in maternal health [71]. It is observed that a well-functioning health system with appropriate supply of equipment, drugs, and other supplies is required for timely management of delivery complications to prevent maternal deaths [2]. Studies found that the utilization of health services may be low because of the gender inequality and status of the women as well as cultural barriers. Empowerment of women and education has shown to positively influence the health-seeking behavior and decrease in maternal mortality [74-77]; thus, efforts should be made to improve this area for sustainability of the interventions to decrease maternal mortality and improve overall health care utilization. 
It is seen that HRH interventions alone cannot improve the functioning and availability of the skilled health workers. There are many other areas to gain the best outcome regarding maternal health. Female education, empowerment, and gender equality should be emphasized [62]. Effective provision of services can only be made possible when huge inequalities in maternal care are removed from the community. The poor-rich inequalities in delivery care can be reduced by providing equal services to all by rigorous efforts made towards equity oriented research, policy making, implementation, and proper monitoring of the services provided [57]. Investment in social and economic development with emphasis on achieving gender equality should be the goal [66]. Similarly, access and availability of affordable transportation in rural areas as well as appropriate supply of drugs, equipment, and infrastructure of the health facilities are needed to improve EmOC and reduce maternal mortality.

\section{Conclusions}

This review suggested an urgent and immediate need for formative evidence-based research on effective HR interventions for improved maternal health in LMICs. The principal challenges in these countries are to strengthen research systems, identify key research questions, and generate the capacity to turn research into practical applications [78]. The studies showed that all the HRH interventions implemented individually or in combination had a positive impact on improving maternal health. However, implementation alone is not enough to bring about this change but also other essential steps like educating and empowering women, alleviating poverty, establishing gender equality, and providing infrastructure, availability of equipment, drugs, and supplies are all an integral part of working towards the achievement of SDGs and reducing maternal mortality. Leaders and stakeholders are required to work together as a team to construct new models of health care according to the individual needs of each country.

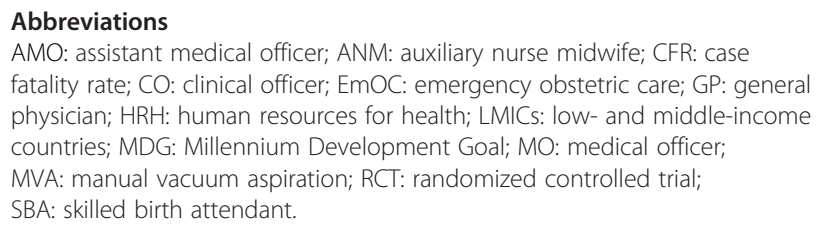

\section{Competing interests}

The authors declare that they have no competing interests.

\section{Authors' contributions}

ZSL and NBM wrote the first draft of the manuscript with subsequent inputs from $B M, A F, K T$, and $Z A B$. ZSL and NM oversaw the systematic review of interventions, with inputs from BM, KT, AF, and ZAB. NBM and ZSL updated the evidence base under the supervision of ZAB. All authors (ZSL, NBM, BM,
$N M, A F, K T, Z A B)$ contributed to writing and review of the paper. All authors read and approved the final manuscript.

\section{Acknowledgements}

This report is part of a wider study commissioned and funded by the WHO/ PMNCH.

\section{Author details}

${ }^{1}$ Division of Women and Child Health, Aga Khan University, Karachi, Pakistan. ${ }^{2}$ Robinson Research Institute, The University of Adelaide, Adelaide, South Australia, Australia. ${ }^{3}$ Department of Maternal Newborn Child and Adolescent Health, World Health Organization, Geneva, Switzerland. ${ }^{4}$ Partnership for Maternal Newborn \& Child Health, Geneva, Switzerland. ${ }^{5}$ Center of Excellence in Women and Child Health, Aga Khan University, Karachi, Pakistan. ${ }^{6}$ Centre for Global Child Health, The Hospital for Sick children, Toronto, Canada.

Received: 14 January 2015 Accepted: 4 March 2016

Published online: 12 March 2016

\section{References}

1. Simwaka BN, Theobald S, Amekudzi YP, Tolhurst R. Meeting Millennium Development Goals 3 and 5. BMJ. 2005;331(7519):708-9.

2. Rasch V. Maternal death and the Millennium Development Goals. Dan Med Bull. 2007;54(2):167-9.

3. Chen L, Evans T, Anand S, Boufford Jl, Brown H, Chowdhury M, Cueto M, Dare L, Dussault G, Elzinga $G$ et al. Human resources for health: overcoming the crisis. Lancet. 2004;364(9449):1984-90.

4. Lewin S, Munabi-Babigumira S, Glenton C, Daniels K, Bosch-Capblanch X, van Wyk BE, Jensen J, Johansen M, Aja GN, Zwarenstein M et al. Lay health workers in primary and community health care for maternal and child health and the management of infectious diseases. Cochrane Database Syst Rev. 2010;3(Issue 3):CD00401.

5. Cometto G, Witter S. Tackling health workforce challenges to universal health coverage: setting targets and measuring progress. Bull World Health Organ. 2013;91:881-5.

6. Travis $P$, Bennett $S$, Haines A, Pang T, Bhutta $Z$, Hyder AA, Pielemeier NR, Mills A, Evans T. Overcoming health-systems constraints to achieve the Millennium Development Goals. Lancet. 2004;364(9437):900-6.

7. Haines A, Cassels A. Can the Millennium Development Goals be attained? BMJ. 2004:329(7462):394-7

8. Bhutta ZA, Lassi ZS, Pariyo G, Huicho L. Global experience of community health workers for delivery of health related Millennium Development Goals: a systematic review, country case studies, and recommendations for integration into national health systems. In.: Global Health Workforce Alliance/World Health Organization. 2010. Available at http://www.who.int/ workforcealliance/knowledge/publications/CHW_FullReport_2010.pdf?ua=1.

9. Speybroeck N, Ebener S, Sousa A, Paraje G, Evans DB, Prasad A. Inequality in access to human resources for health: measurement issues. Geneva: World Health Organization; 2006.

10. Sousa A, Tandon A, Dal Poz MR, Prasad A, Evans DB. Measuring the efficiency of human resources for health in attaining health outcomes across sub national units in Brazil. Geneva: World Health Organization; 2006.

11. World Health Organization. The world health report: working together for health. 2006

12. Efendi F. Health worker recruitment and deployment in remote areas of Indonesia. Rural Remote Health. 2012;12:2008.

13. Zurn P, Dal Poz MR, Stilwell B, Adams O. Imbalance in the health workforce. Hum Resour Health. 2004;2(1):13.

14. Ferrinho P, Van Lerberghe W, da Cruz GA. Public and private practice: a balancing act for health staff. Bull World Health Organ. 1999;77(3):209.

15. Kirigia JM, Gbary AR, Muthuri LK, Nyoni J, Seddoh A. The cost of health professionals' brain drain in Kenya. BMC Health Serv Res. 2006;6:89.

16. Lassey AT, Lassey PD, Boamah M. Career destinations of University of Ghana Medical School graduates of various year groups. Ghana Med J. 2013;47(2):87-91.

17. Lehmann U, Dieleman M, Martineau T. Staffing remote rural areas in middle- and low-income countries: a literature review of attraction and retention. BMC Health Serv Res. 2008;8:19.

18. Ramani S, Rao KD, Ryan M, Vujicic M, Berman P. For more than love or money: attitudes of student and in-service health workers towards rural service in India. Hum Resour Health. 2013;11:58. 
19. Anyangwe SC, Mtonga C. Inequities in the global health workforce: the greatest impediment to health in sub-Saharan Africa. Int J Environ Res Public Health. 2007;4(2):93-100.

20. Berer M. Maternal mortality and morbidity: is pregnancy getting safer for women? Reprod Health Matters. 2007;15(30):6-16.

21. Brugha R, Pritze-Aliassime S. Promoting safe motherhood through the private sector in low-and middle-income countries. Bull World Health Organ. 2003;81:616-23.

22. Ozgediz D, Riviello R. The "other" neglected diseases in global public health: surgical conditions in sub-Saharan Africa. PLoS Med. 2008;5(6):e121.

23. Lassi ZS, Cometto G, Huicho L, Bhutta ZA. Quality of care provided by mid-level health workers: systematic review and meta-analysis. Bull World Health Organ. 2013;91:824-33.

24. Barker CE, Bird CE, Pradhan A, Shakya G. Support to the Safe Motherhood Programme in Nepal: an integrated approach. Reprod Health Matters. 2007;15(30):81-90

25. de Bernis L, Sherratt DR, AbouZahr C, Van Lerberghe W. Skilled attendants for pregnancy, childbirth and postnatal care. Br Med Bull. 2003;67(1):39.

26. 2012 list of developing countries. In: World Bank; 2012. Available at https://www.usaid.gov/sites/default/files/documents/1876/310maa.pdf. Accessed on 21 June 2012

27. Deeks JJ, Altman DG, Bradburn MJ. Statistical methods for examining heterogeneity and combining results from several studies in meta-analysis. London: BMJ Books; 2001.

28. Loevinsohn BP. Health education interventions in developing countries: a methodological review of published articles. Int J Epidemiol. 1990;19(4):788-94.

29. HRH action framework. In: Capacity Project, Global Health Workforce Alliance. United States Agency for International Development, World Health Organization; 2007. Available at: http://www.capacityproject.org/framework/.

30. Dusitsin NCS, Varakamin S, Boonsiri B, Ningsanon P, Gray RH. Post-partum tubal ligation by nurse-midwives and doctors in Thailand. Lancet. 1980;1 (8169):638-9.

31. Eren N, Ramos R, Gray RH. Physicians vs. auxiliary nurse-midwives as providers of IUD services: a study in Turkey and the Philippines. Stud Fam Plann. 1983;14(2):43-7.

32. Warriner IKMO, Hoffman M, Morroni C, Harries J, My Huong NT, et al. Rates of complication in first-trimester manual vacuum aspiration abortion done by doctors and mid-level providers in South Africa and Vietnam: a randomised controlled equivalence trial. Lancet. 2006;368(9551):1965-72.

33. Warriner IKWD, Huong NT, Thapa K, Tamang A, Shah I, et al. Can midlevel health-care providers administer early medical abortion as safely and effectively as doctors? A randomised controlled equivalence trial in Nepal. Lancet. 2011;377(9772):1155-61.

34. Mekbib T, Kassaye E, Getachew A, Tadesse T, Debebe A. The FIGO save the mothers initiative: the Ethiopia-Sweden collaboration. Int J Gynaecol Obstet. 2003;81(1):93-102.

35. Djan JO, Kyei-Faried S, Twum S, Danquah JBO, Ofori M, Browne ENL, Pmm Team TK. Upgrading obstetric care at the health center level, Juaben, Ghana. Int J Gynaecol Obstet. 1997:59:83-90.

36. Ifenne D, Essien E, Golji N, Sabitu K, Alti-Mu'azu M, Musa A, Adidu V, Mukaddas M. Improving the quality of obstetric care at the teaching hospital, Zaria, Nigeria. Int J Gynaecol Obstet. 1997;59:37-46.

37. Kruk ME, Pereira C, Vaz F, Bergstrom S, Galea S. Economic evaluation of surgically trained assistant medical officers in performing major obstetric surgery in Mozambique. BJOG. 2007:114(10):1253-60.

38. Lawn JE, Tinker A, Munjanja SP, Cousens S. Where is maternal and child health now? Lancet. 2006;368(9546):1474-7.

39. McCord C, Mbaruku G, Pereira C, Nzabuhakwa C, Bergstrom S. The quality of emergency obstetrical surgery by assistant medical officers in Tanzanian district hospitals. Health Aff. 2009;28(5):w876.

40. Ohnishi M, Nakamura K, Takano T. Training of healthcare personnel to improve performance of community-based antenatal care program. Adv Health Sci Educ Theory Pract. 2007;12(2):147-56.

41. Rana TG, Chataut BD, Shakya G, Nanda G, Pratt A, Sakai S. Strengthening emergency obstetric care in Nepal: the Women's Right to Life and Health Project (WRLHP). Int J Gynaecol Obstet. 2007:98(3):271-7.

42. Combine learning approaches to improve maternal health. In. Edited by Motherhood GS. Washington D.C. Population Council; 2006.

43. Pereira C, Bugalho A, Bergström S, Vaz F, Cotiro M. A comparative study of caesarean deliveries by assistant medical officers and obstetricians in Mozambique. BJOG. 2005;103(6):508-12.
44. Chilopora GPC, Kamwendo F, Chimbiri A, Malunga E, Bergström S. Postoperative outcome of caesarean sections and other major emergency obstetric surgery by clinical officers and medical officers in Malawi. Hum Resour Health. 2007;14(5):17.

45. Akashi H, Yamada T, Huot E, Kanal K, Sugimoto T. User fees at a public hospital in Cambodia: effects on hospital performance and provider attitudes. Soc Sci Med. 2004;58(3):553-64

46. Koblinsky M, Anwar I, Mridha MK, Chowdhury ME, Botlero R. Reducing maternal mortality and improving maternal health: Bangladesh and MDG 5. J Health Popul Nutr. 2009;26(3):280.

47. Rath AD, Basnett I, Cole M, Subedi HN, Thomas D, Murray SF. Improving emergency obstetric care in a context of very high maternal mortality: The Nepal Safer Motherhood Project 1997-2004. Reprod Health Matters. 2007;15(30):72-80

48. Islam MT, Haque YA, Waxman R, Bhuiyan AB. Implementation of emergency obstetric care training in Bangladesh: lessons learned. Reprod Health Matters. 2006;14(27):61-72.

49. Jamisse L, Songane F, Libombo A, Bique C, Faúndes A. Reducing maternal mortality in Mozambique: challenges, failures, successes and lessons learned. Int J Gynaecol Obstet. 2004;85(2):203-12.

50. Kayongo M, Butera J, Mboninyibuka D, Nyiransabimana B, Ntezimana A Mukangamuje V. Improving availability of EmOC services in Rwanda-CARE's experiences and lessons learned at Kabgayi Referral Hospital. Int J Gynaecol Obstet. 2006;92(3):291-8.

51. Kayongo M, Esquiche E, Luna MR, Frias G, Vega-Centeno L, Bailey P. Strengthening emergency obstetric care in Ayacucho, Peru. Int J Gynaecol Obstet. 2006;92(3):299-307.

52. Santos C, Diante D, Baptista A, Matediane E, Bique C, Bailey P. Improving emergency obstetric care in Mozambique: the story of Sofala. Int J Gynaecol Obstet. 2006:94(2):190-201.

53. Monica Desai JWR, Adisasmito W, Mounier-Jack S, Coker R. Critica interactions between Global Fund-supported programmes and health systems: a case study in Indonesia. Health Policy Plan. 2010;25 Suppl 1:143-7.

54. Campbell OMR. What are maternal health policies in developing countries and who drives them? A review of the last half-century. Safe motherhood strategies: a review of the evidence 2000

55. Chowdhury ME, Ahmed A, Kalim N, Koblinsky M. Causes of maternal mortality decline in Matlab. Bangladesh J Health Popul Nutr. 2009;27(2):108.

56. Gill K, Pande R, Malhotra A. Women deliver for development. Lancet. 2007;370(9595):1347-57.

57. Houweling TAJ, Ronsmans C, Campbell OMR, Kunst AE. Huge poor-rich inequalities in maternity care: an international comparative study of maternity and child care in developing countries. Bull World Health Organ. 2007:85:745-54

58. Falconer A, Crisp E, Warick C, Day-Strik F. Scaling up human resources for women's health. BJOG. 2009;116 Suppl 1:11-4

59. Abe E, Omo-Aghoja LO. Maternal mortality at the Central Hospital, Benin City Nigeria: a ten year review. Afr J Reprod Health. 2008;12(3):17-26.

60. Gupta M, Mavalankar D, Trivedi P. A study of referral system for EmOC in Gujarat. 2009

61. Mavalankar D, Sriram V. Provision of anaesthesia services for emergency obstetric care through task shifting in South Asia. Reprod Health Matters. 2009:17(33):21-31.

62. Costello A, Azad K, Barnett S. An alternative strategy to reduce maternal mortality. Lancet. 2006;368(9546):1477-9.

63. Figo SM. Human resources for health in the low-resource world: collaborative practice and task shifting in maternal and neonatal care. Int $J$ Gynaecol Obstet. 2009;105(1):74-6.

64. Mridha MK, Anwar I, Koblinsky M. Public-sector maternal health programmes and services for rural Bangladesh. J Health Popul Nutr. 2009;27(2):124.

65. Filippi V, Ronsmans C, Campbell OMR, Graham WJ, Mills A, Borghi J, Koblinsky M, Osrin D. Maternal health in poor countries: the broader context and a call for action. Lancet. 2006;368(9546):1535-41.

66. ten Hoope-Bender P, Liljestrand J, MacDonagh S. Human resources and access to maternal health care. Int J Gynaecol Obstet. 2006;94(3):226-33.

67. Adegoke AA, van den Broek N. Skilled birth attendance-lessons learnt. BJOG. 2009;116(s1 International Reviews):33-40.

68. Naicker S, Plange-Rhule J, Tutt RC, Eastwood JB. Shortage of healthcare workers in developing countries—Africa. Ethn Dis. 2009;19(1):60.

69. Serour Gl. Healthcare workers and the brain drain. Int J Gynaecol Obstet. 2009;106(2):175-8. 
70. Anwar I, Kalim N, Koblinsky M. Quality of obstetric care in public-sector facilities and constraints to implementing emergency obstetric care services: evidence from high-and low-performing districts of Bangladesh. J Health Popul Nutr. 2009;27:139-55.

71. Mavalankar DV, Vora KS, Ramani KV, Raman P, Sharma B, Upadhyaya M. Maternal health in Gujarat, India: a case study. J Health Popul Nutr. 2009;27(2):235

72. Narchi NZ. Exercise of essential competencies for midwifery care by nurses in São Paulo, Brazil. Midwifery. 2009;27(1):23-9.

73. Olenja J, Godia P, Kibaru J, Egondi T. Influence of provider training on quality of emergency obstetric care in Kenya. Calverton, Maryland, USA: Macro International Inc; 2009.

74. Bhuiya A, Hanifi SMA, Mahmood SS. Action monitoring for equity and gender in health. J Health Popul Nutr. 2009;26(3):378.

75. Cotter K, Hawken M, Temmerman M. Low use of skilled attendants' delivery services in rural Kenya. J Health Popul Nutr. 2006;24(4):467.

76. Fernando D, Jayatilleka A, Karunaratna V. Pregnancy-reducing maternal deaths and disability in Sri Lanka: national strategies. Br Med Bull. 2003;67(1):85.

77. Simkhada B, Teijlingen ER, Porter M, Simkhada P. Factors affecting the utilization of antenatal care in developing countries: systematic review of the literature. J Adv Nurs. 2008;61(3):244-60.

78. Kayentao K, Garner P, van Eijk AM, Naidoo I, Roper C, Mulokozi A, MacArthur JR, Luntamo M, Ashorn P, Doumbo OK et al. Intermittent preventive therapy for malaria during pregnancy using 2 vs 3 or more doses of sulfadoxinepyrimethamine and risk of low birth weight in Africa systematic review and meta-analysis. JAMA. 2013;309(6):594-604.

79. World Health Organization. Making pregnancy safer: the critical role of the skilled attendant. Geneva: A joint statement by WHO, ICM \& FIGO. WHO; 2004.

80. Graham W. Can skilled attendance at delivery reduce maternal mortality in developing countries? Safe motherhood strategies: a review of the evidence. In. Edited by W. DBWL. Antwerp: Studies in Health Services Organisation \& Policy; 2001.

81. Mcdonald, Starr. Saving women's lives, improving newborn health. Washington: Family Care International; 2002

82. MacDonagh S. Achieving skilled attendance for all; a synthesis of current knowledge and recommended actions for scaling up. London: DFID Health Resource Centre; 2005.

\section{Submit your next manuscript to BioMed Central and we will help you at every step:}

- We accept pre-submission inquiries

- Our selector tool helps you to find the most relevant journal

- We provide round the clock customer support

- Convenient online submission

- Thorough peer review

- Inclusion in PubMed and all major indexing services

- Maximum visibility for your research

Submit your manuscript at www.biomedcentral.com/submit 